\title{
“GOOD MORNING PROFESSOR, SO YOU ARE HERE TO EVALUATE THEM?" CHALLENGES AND OPPORTUNITIES IN ETHNONURSING
}

\author{
Maria Augusta Grou Moita', Alcione Leite da Silva²
}

\footnotetext{
${ }^{1}$ Nursing Doctoral Student. Professor at Escola Superior de Enfermagem de Lisboa, Portugal. E-mail: agmoita@esel.pt

2 Ph.D. in Philosophy of Nursing. Associate Visiting Professor of the Department of Health Sciences at Universidade de Aveiro, Portugal. E-mail: alsilva@ua.pt
}

\begin{abstract}
The role of the ethnographer can be extremely demanding and challenging. This professional frequently experiences unexpected situations and feelings, which result in deep reflections and cause unpredictable problem resolution strategies to emerge. In this study, we reflected on the experience of living this role, based on a study of Ethnonursing. This reflection is based on an excerpt from the field notes of this study. The reflection was adjusted theoretically and complemented the analysis of the implementation of enablers proposed by Leininger in this type of study. The ambiguities, difficulties, contradictions, challenges and possibilities that emerged from the experienced role led to the broadening of knowledge, an awareness of the multiple roles experienced, the importance of care development, the relevance of being accepted by the other, the sharing of experiences and the development of cultural competence. We consider that this role has changed us, promoting our growth as people and as researchers.
\end{abstract}

DESCRIPTORS: Transcultural nursing. Nursing research. Methodology.

\section{“BOM DIA PROFESSORA, ENTÃO VEM CÁ PARA OS AVALIAR?" DESAFIOS E POSSIBILIDADES DA ETNOENFERMAGEM}

RESUMO: O papel do(a) etnógrafo(a) pode ser extremamente exigente e desafiador. É frequente a vivência de situações e sentimentos inesperados, que originam reflexões profundas e fazem emergir estratégias imprevisíveis de resolução de problemas. Neste sentido, refletimos sobre a vivência deste papel a partir de um estudo de Etnoenfermagem. Esta reflexão tem como base um excerto retirado das notas de campo deste estudo. Enquadramos teoricamente a reflexão e a complementamos com a análise da implementação dos guias propostos por Leininger neste tipo de estudo. As ambiguidades, dificuldades, contradições, desafios e possibilidades que emergiram do papel experienciado, conduziram-nos ao aprofundamento de conhecimentos, à conscientização dos múltiplos papéis vivenciados, à importância do desenvolvimento da atenção, à relevância de se ser aceito pelo outro, à partilha de experiências e ao desenvolvimento da competência cultural. Consideramos que este papel nos transformou e promoveu o nosso crescimento como pessoas e investigadoras. DESCRITORES: Enfermagem transcultural. Pesquisa em enfermagem. Metodologia.

\section{BUENOS DIAS PROFESORA, ENTONCES VIENE PARA EVALUAR?" DESAFIOS Y POSIBILIDADES DE ETNOENFERMERÍA}

RESUMEN: El papel del(a) etnógrafo(a) puede ser exigente y desafiante. A menudo, se experimentan situaciones inesperadas y sentimientos que originan profundas reflexiones y el surgimiento de estrategias imprevistas para resolver problemas. En este sentido, nos proponemos reflexionar sobre la experiencia de este papel a partir de un estudio de Etno-enfermería. Esta reflexión se basa en un extracto tomado de las notas de campo de este estudio. Se encuadró teóricamente y complementó con un análisis de la aplicación de las guías propuestas por Leininger. Las ambigüedades, dificultades, contradicciones, desafíos y posibilidades que surgieron, nos ha llevado a profundizar el conocimiento, a tomar conciencia de las múltiples funciones vividas, a darse cuenta de la importancia de desarrollar la atención, a resaltar de ser aceptado por los demás, a compartir experiencias y a desarrollar la competencia cultural. Creemos que este papel nos ha transformado y ha promovido nuestro crecimiento como personas e investigadores.

DESCRIPTORES: Enfermería transcultural. Investigación en enfermería. Metodología. 


\section{INTRODUCTION}

For the ethnographer, entering the world of the informers constitutes an intense moment of unexpected situations and emotions. Despite knowing theoretically how to develop this role, the ethnographer is often forced to react to the occasion and search for the best answer for what is being experienced. It is, in fact, a demanding and challenging role, which leads to moments of deep introspection.

We felt impelled to reflect on our role as ethnographers when we faced an unpredicted situation during field work for an Ethnonursing study. The study in question was developed for a doctoral degree in nursing at the University of Lisbon. Based on Leininger's Theory of Cultural Care, the study purpose was to learn the convergences and divergences of the cultural care developed by immigrant Ukrainian nurses in Portugal.

After the statement which follows, which was extracted from the field notes of the first author, we reflected critically on our role as ethnographers, adjusting our role to a theoretical base and contextualizing it with the experience of other researchers. By conceptualizing the ethnonursing method, Leininger ${ }^{1}$ suggests the use of enablers to assist the researchers during the study. The adoption of this method aims at showing the challenges and opportunities discovered in the development of the study.

\section{Delta Medical Service*}

I get to work at around 10h. I have to check the schedule of the Ukrainian nurses that work here to organize my field visits, as they work in shifts and sometimes there are changes.

Since I know the service, due to a previous experience in students' counseling, I go immediately to the office. There, next to the cabinets where the serum is kept, I find nurse Dália, who I had already met in this same area. The nurse immediately greets me with a smile and asks:

Nurse Dália - Good morning professor, so you are here to evaluate them?

I ["I bite my tongue and lose my enthusiasm. I smile anyway, hoping my smile does not seem forced] - Good morning, nurse Dália. No! I am not here to evaluate them, I am the student now, and I am here to learn from them.
I try to show enthusiasm, but I feel that her comment just gave me a cold shower. In a fraction of a second several concerns go through my mind. If this is what the nurse thinks, the other service nurses are going to think the same, not to mention the Ukrainian nurses that I chose as key-informers and who were my students. I should not be wearing the school uniform, but it actually facilitates my ability to move around inside the hospital. What should I do? How can I change this idea conceived by the nursing professionals of this unit?

Nurse Dália [looking at me and frowning with doubt] - You are here to learn from them?

\section{I - Yes! I want to learn from them.}

Then I explain the purpose of the study, the field work that I want to start that week and the interviews that I intend to do later. The nurse listens to me closely but does not look very convinced. I try, mentally, to compile a list of reasons for this reaction: Is it because I am at school, and then I have nothing to learn from the students? Is it because I have nothing to learn from these nurses in particular, because they are foreigners? I tried not to think about it, afraid to consider reasons associated with discrimination and ethnocentrism.

I keep talking to nurse Dália and I explain that I am going to follow the Ukrainian nurses during their morning, afternoon and night shifts, and that I would like to start that week. I also mention that I have already spoken to the head nurse and arranged with her to come to the service to check the schedule and see which shifts these nurses would be working. The nurse nods her head positively and takes the shift schedule from the notice board, on the wall behind her. She hands it to me and wishes me good luck with my work. I thank her and sit at the center table of the office to transcribe the schedule (O3).

\section{THE ETHNONURSING METHOD}

In the 1960s, Leininger created the research method called ethnonursing, ${ }^{1-4}$ in order to understand nursing phenomena, especially those related to the Theory of Cultural Care or Theory of Cultural Care Diversity and Universality. The author defines it as a qualitative and inductive method of research which studies, documents, describes, understands, explains and interprets the points of view of the people and the meanings of their daily life experiences related to human care, health and well-being. It is a method that allows the discovery of phenomena from a macro or mi-

* In order to guarantee privacy, all the names of places and people have been changed. 
cro perspective, depending on the study domain chosen by the researcher. ${ }^{1}$

Ethnonursing has some similarities to ethnography, but differs in its focus and purpose. Ethnonursing focuses on nursing phenomena, such as care, well-being, health and disease, aimed at building knowledge in nursing, particularly the way it is understood and experienced by nurses and by the people who are treated by them. ${ }^{1-4}$

Regarding the similarities, both ethnonursing and ethnography share a common epistemological and philosophical base and use similar methods of data collection - the participating observation and the interview. ${ }^{2,4}$ Both methods allow an emic view of events, although they do not neglect the etic perspective, which is also documented, described and explained, providing contrasting views of the studied phenomenon. They consist of methods centered on people, with an intense involvement between researcher and informer aimed at understanding their experiences and lifestyles. By adopting the role of learner, the researcher obtains comprehensive, contextual and firsthand information regarding the studied phenomenon. $^{2}$

In the conceptualization of the ethnonursing method, Leininger ${ }^{1}$ suggests the use of six enablers to assist the researcher during the study, specified as follows:

1. The Domain of Inquiry Enabler - expected to comprehend all aspects - words or ideas - regarding what the researcher intends to study, helping the centralization of the cultural care.

2. The Sunrise Enabler - used to comprehensively explore the multiple influences of cultural care. The several components of Leininger's theory are represented in it: the way an interrelationship is formed between the components of the world view and dimensions of cultural and social structures (beliefs, cultural values and life paths, religion, philosophy and spiritual beliefs, economic factors, educational beliefs, technological perspectives, parentage and social networks, political and legal factors) and the context of the language and the environment. Similarly, the influence of all of these aspects is evident in the standards of care and human practices, as well as in the well-being and health of people, families, groups, institutions and communities.
3. The Stranger to Trusted Friend Enabler used to guide the researcher when entering the informer's world, in order to be accepted and to become a trusted friend, distancing himself/herself from the position in which he/she is seen as a stranger. In this process, the researcher is forced to perform constant self-evaluations and to reflect. In the position of a friend, the researcher must meet certain conditions to collect emic, authentic and credible information.

4. The Three Phase Observation-ParticipationReflection Enabler (O-P-R) - used to guide the researcher in making observations focused on the environment of the informers. From the position of complete observer, the researcher moves gradually to the stage of participation and, finally, to the stage of reflection and confirmation of the data collected from the informers.

5. The Ethnodemographic Enabler - employed to collect information from the informers related to their life story.

6. The Acculturation Enabler - used to identify the approach versus the distancing from their own culture.

The use of these enablers assists the researcher in the development of the ethnonursing method, enabling examination of the main characteristics of the Culture Care Theory and focusing on the domain of inquiry. Leininger ${ }^{1}$ highlights that these enablers should not and cannot constitute a barrier that prevents the researcher from collecting new information in an informal and spontaneous way. In her opinion, the ethnonursing process has to be flexible so that the researcher may follow up people in their natural contexts.

It is important to highlight some characteristics of Leininger's theory, namely the simplicity, generality, empirical accuracy and derivable consequences. ${ }^{5}$ Simplicity results from the opinions of nursing undergraduate students and nurses that, despite knowledge of anthropology and transcultural nursing being necessary to use it with strictness, when acquired is very practical, relevant and useful. They also consider that it is easy to mentally appropriate the sunrise model and practice it. Despite this simplicity, it is curious that some postgraduate nursing students still choose to use the nursing process as a study methodology in their studies based on the theory of Leininger, rather than the sunrise model. ${ }^{6}$ 
Resuming the characteristics of Leininger's theory, ${ }^{5}$ theory generality is attributed to the holistic, polyvalent, multicultural and universal perspective it presents. Concerning empirical accuracy, it is evident that the theory is susceptible to investigation and that the proposed research method of ethnonursing is rigorous. Finally, the derivable consequences, or the results of the application of the theory, have been considered important in nursing. These results are being used in practice, in teaching and in nursing research. The fact that the care concept is the center of interest of the theory is a fundamental aspect for the progress of nursing knowledge and practice.

\section{CHALLENGES AND OPPORTUNITIES IN ETHNONURSING}

Based on what has been previously discussed, a challenge arises concerning how to operate in the field, utilizing the several enablers proposed by Leininger. It was clear to us that we wished to learn about the professional care developed by Ukrainian nurses working in Portugal. This was the study dimension and the basis on which we could implement the sunrise model. It was the base to discover, from the perspective of these nurses, the other dimensions of the model, a possibility due to the flexibility of this model. The sunrise model allows a visual image of the conceptual components of Leininger's theory, which may be considered one of its strong points since the existence of this model guides the collection of information. ${ }^{7}$ Nevertheless, a question emerged: how is it possible to "enter the world" of the nurses from a transcultural perspective?

\section{Broadening knowledge}

The study of the history of Ukraine, their beliefs, cultural values and lifestyles, politics, economy, education, religion and all other factors comprising the dimensions of the cultural and social structure, as well as the aspects related to health care in the popular and professional system, increased our cultural sensitivity. We recognize that until then we had poor knowledge regarding this domain, which is designated in the literature as the stage of conscious incompetence in the process of obtaining cultural knowledge. ${ }^{8}$ This study, previously developed at the beginning of the field work, was essential and motivated us to approach the Ukrainian nurses and to wish to learn from them.
Returning to the question of the sunrise model, Leininger-3 ${ }^{2-3}$ commends that it not be viewed as a linear model that controls variables, but in an open, flexible and naturalist way so that it is possible to obtain subjective and objective information regarding cultural care. These are also the characteristics of the ethnonursing model, so it appears that theory and method are closely interconnected. This knowledge was helpful in facing the entire process with tranquility, in light of the nuances that the care assumes, and which are not always visible at first glance.

Motivated by the desire to discover the convergences and divergences of the cultural care practiced by the studied Ukrainian nurses, in face of the Portuguese reality, our purpose was to understand how they made their decisions and acted upon them, in the three modalities of proposed decision-action. ${ }^{3}$ Hence, it was possible to learn the way these nurses preserved, adapted and/or re-structured their cultural care practices, knowing they were guided by the need to be culturally congruent with the new context in which they found themselves. ${ }^{3}$

We appreciate the knowledge of the informers (the emic perspective); at the same time, we compared and contrasted this knowledge with our studies (the etic perspective), seeking a more comprehensive knowledge of the phenomenon under study.

\section{Experiencing multiple roles}

The fact that the first author knew the studied nurses, due to being an educator in their equivalence process to the Portuguese nursing course, raised two types of questions. On the one hand, the first author was no longer a stranger and had already taken some steps in the continuum that ends in trust and friendship. On the other hand, the role that was now assumed, that of learner, was opposed to the previous role of educator and evaluator, and seemed to emerge in a more hesitant and weaker way.

Despite the fact that the first author mentioned that she was a doctoral candidate, showing an identification badge with this information and wearing a uniform similar to the nurses, the established image would not change automatically. Her position as learner had been restated several times, but the distrust was evident. Although we hoped the role of ethno-nurse-researcher would deconstruct the one of educator and evaluator, 
the latter was still remarkable strong. The role of educator was fundamental in helping this group of nurses to insert themselves into the Portuguese nursing culture and to adapt to a different work dynamic, particularly in the health institutions of this new reality. These aspects were determinants in the nurses being successfully inserted into the Portuguese labor market. At this time, the situation was different and we wanted to discover the convergences and divergences between the nursing care developed by the nurses in Portugal and the care practiced in their original country, without the spectrum of any professional performance evaluation looming over them.

This duality of roles is also the target of reflection of another researcher, who was a nurse and administrator. ${ }^{9}$ As a nurse, the researcher considers herself to be an insider of the profession and, as an employee, she is an insider of the organization. Nevertheless, being an administrator who does not develop clinical practice, and is not an expert in the area in which her study was developed, she became, to a certain degree, an outsider. As such, she was capable of distancing herself conceptually from the events and observing them with the necessary objectivity of a researcher. However, although she was careful to disclose that she was there solely as a researcher, the studied nurses took the opportunity to ask questions related to the management area, associating these two roles simultaneously. For the researcher, there were times this situation became confusing and conflicting.

The "multiple realities"10:39 experienced derive from the diversity of the study participants and the diversity that exists within each individual. The interior diversity may emerge in inconsistencies in the course of the same interview, or in discrepancies between what is done and what is said to be done. ${ }^{10}$

\section{Developing attention}

The aspect previously referred to constitutes a challenge that kept us on alert and forced us to continuously self-evaluate the behaviors and attitudes regarding them. This whole process impelled us to be flexible and to search for a resolution for the problems found, as is also referred to in a study with institutionalized older people. ${ }^{11}$ It concerned an experience in which the senses remained permanently awakened, in an opening process of unexpected possibilities. ${ }^{10}$
We recognize that being in a state of hypervigilance is very demanding work, but it certainly leads to a broader knowledge of the surrounding context and the relationships established among the several intervening agents, which we aimed to describe in as much detail as possible in the field notes. Nevertheless, due to the fact that we are nurses, and consequently familiar with the nursing culture, we felt like we needed to give much more attention to observing to avoid influencing the studied reality, both through our words and by our actions. We were afraid that, by having that internalized within ourselves, we would spontaneously use it without being aware of our possible influence on the nursing care context.

On the other hand, even though this aspect was considered, there was the risk of influencing the answers of the informers because we belonged to the same professional group. A study approached this question by focusing on the convergences and divergences in the values and practices of nursing care in Anglo-American and Philippine-American nurses at an American hospital. ${ }^{12}$ Due to the fact that the author was a Filipino professor and nurse (although she had been living in the United States for 22 years), the author believed she influenced the answers of the informers, who were initially quite reserved. In her opinion, this situation did not necessarily constitute a breach since her past helped her to be more attentive in her analysis.

\section{Working on acceptance}

Similar to the experience of other authors, ${ }^{12}$ there were also reservations on the part of the key-informers of this study, in opposition to the acceptance of patients and other professionals who confused us with nurses of the service and even requested our help, perhaps because they were not aware of the purpose of our presence in that context. Did the reservations of the key-informers result from the fact that they felt they were being evaluated by us? Or was it related to the forced exposure due to our presence in the service?

It is necessary to evidence the danger of a relationship with compromised trust, when participants are forced to take part in the study and the researcher is perceived to be in a position of power, even when the procedures for obtaining a written consent have been followed. ${ }^{13}$ A similar situation was experienced by an administrative nurse when she became aware that the group of nurses participating in the study might feel forced 
to participate, despite her having reinforced with them that any refusal to participate would not be viewed negatively. ${ }^{9}$ In fact, the experience of this role is still ambiguous and demands a transformation and redefinition of ourselves, which also happened to another researcher ${ }^{10}$ in his ethnographic study in the area of education.

By trying to avoid the condition of being an intruder, we kept in mind some guiding principles of authors in the area. For instance, it is fundamental to have a conscious attitude of almost complete ignorance to be able to capture the meaning of the actions and events for the people who are participating in the study..$^{14}$ Leininger ${ }^{15}$ also reinforces the need to keep an open mind, be an active listener and have a genuine attitude of wanting to learn. In another perspective, it is necessary to remember that the researcher's presence in the study location introduces a series of new social relationships, since the direct observation and the communication are interaction processes that are being reorganized as the study is developed. ${ }^{16} \mathrm{It}$ is important not to avoid interference but to be aware of it, controlling and objectifying it, both during the process of data production and during its analysis. ${ }^{16}$

Hence, we aimed at adopting a few strategies to promote the acceptance of our new role, following up and observing the care developed by this group of nurses in the different work shifts. Thus, we approached the work reality of these professionals during our observation of the morning, afternoon and night shifts. This fact allowed us to make detailed observations regarding the care developed with patients which, despite continuing uninterruptedly for 24 hours has specific expressions in each shift. This strategy was also used in other contexts, ${ }^{12,17}$ which reinforces the importance of having a broad and complete view of the service dynamics, as well as the work of the nurses, allowing one to develop cultural sensitivity for the studied context. Moreover, the hospital shift schedule differs from the teaching schedule, which may also positively influence the acceptance of this new role. In fact, the different strategies used strengthen the richness of the collected information, promote the approach to the group and develop methodological strictness. ${ }^{6}$

Still, considering the fragility of this role, we intentionally "distanced" ourselves from the other nurses of the service, so that these meetings were not interpreted by the Ukrainian nurses as a transmission of information regarding the observed performance. A similar situation was also mentioned in another study, regarding the "distancing" of the chief nurse, in her ethnographic study of nurses who provide care to older people. ${ }^{17}$ Hence, the relationship of trust we managed to develop and expected to strengthen began to be established.

Nevertheless, we still felt ambivalent in terms of how to deal with comments received from several members of the group: the professor helped us in our equivalency exams, and now we are helping you. We were sensitized to this verbalization of assistance, which we believed to be genuine and was materialized, for instance, through information regarding their professional experiences in the Ukraine. However, at times, there were doubts regarding whether they were doing this because they felt obligated to.

Regarding our request to be addressed by our names, the result did not meet our expectations. Only a few nurses did it, almost out of fear, looking uncomfortable while doing so. Did the previous experience in the roles of professor and student prevent this familiarity?

\section{Sharing experiences and developing cultural competence}

Concerning the enablers proposed by Leininger ${ }^{3}$, namely the Observation-ParticipationReflection Enabler, it was verified that it was not easy to be complete observers, as recommended by the author, when the work rhythm around us, especially on the morning shifts, was very intense. Moreover, the care provided to the patients demanded privacy, which was their right, so the curtains had to be kept closed. Hence, how can we observe without participating? At these moments it was not possible, and we collaborated with the nurses, holding a patient or helping him/her move. On reflection, we realized it was not possible to dissociate this process, and we served as conductors on the path to the emic perspective of the participants.

Gradually, our permanence in the field brought us closer to the Ukrainian nurses. This was shown by the fact that they shared their life stories and some private moments outside the hospital, such as an invitation for us to attend the Easter ceremony at the Orthodox Church. Equally, we were confirming that they were not afraid to make critical comments in our presence regarding the service or their operational dynamics. 
Although the sharing of episodes in their lives occurred during the fieldwork, this was further emphasized during the interviews. The will to help us was manifested by the emotions which emerged during the discourse, showing the difficult paths taken from the Ukraine to Portugal, the means of survival, the hard work involved in resuming work as nurses and the effort to be accepted as equals by their partners. In these statements, we began to perceive their efforts to be inserted into the Portuguese culture; at the same time they tried to preserve Ukrainian life habits that translated their cultural and social individuality.

By reflecting on our experience since our decision to develop this study, we remember the Model of Campinha-Bacote-The Process of Cultural Competence in Health Care ${ }^{8}$ which we used in a previous study. This model exemplifies our experience in using ethnonursing. The development of cultural competence is a dynamic process rather than a purpose, in which five inseparable concepts intertwine: cultural awareness, cultural knowledge, cultural meeting, cultural abilities and cultural desire. The latter is considered a structural concept in the development of cultural competence. ${ }^{8}$

During this period, we felt that our cultural awareness was heightened. We became more sensitive, admiring and defending the values, beliefs, life habits, practices and strategies for problem resolution used in the Ukrainian culture. In the author's opinion, these aspects characterize this concept. We were led to examine our own values and preconceptions and to become aware of our ethnocentrism. In the role of educators, we tend to believe that our nursing care is the best, since we study and teach it. Despite knowing, theoretically, that care may have different expressions that reveal the individuality of the person providing it, the practice automatically raises a beneficial comparison in our favor. It was evident that this position had to be immediately reviewed.

Regarding cultural knowledge, it is evident that it was developed in our study through the search for information regarding the Ukrainian culture, and was later grounded by the cultural meetings with the nurses in the study. These meetings developed our sensitivity and the knowledge of what is and what is not explicit. Cultural abilities, in which observation and communication play a fundamental role, are translated in the ability to collect culturally relevant data. Moreover, in this domain, we felt that our abilities were being gradually refined.
Finally, cultural desire reflects the person's motivation to want to be involved in the process of cultural competence, which is different from having to be involved in this process. ${ }^{8}$ It is translated by the congruence among words, actions and feelings. Cultural desire particularly touched us, and we feel that it has been present since the beginning, leading us to believe in this project and to have the enthusiasm and motivation to see it through to the end. The greatest purpose of cultural desire is the responsibility to build knowledge that may subsidize quality nursing care for the Ukrainian people who seek health services in Portugal. We share the opinion that an ethnographic study must, in addition to studying the practice, also instigate change. ${ }^{18}$ Thus we are left with the challenge to overcome mere cultural sensitivity and strive to incorporate the findings of this transcultural study into daily practice.

\section{CONCLUSION}

Ethnonursing, being the only research method associated with nursing, constitutes a relevant method in the discovery of human care and the phenomena related to the nursing discipline and profession. The use of this method impels the discovery of knowledge, which promotes the quality of nursing care from a transcultural perspective.

Nevertheless, the implementation of ethnonursing brings challenges and opens possibilities to researchers in their role as ethnographers, which may not always be predicted at the beginning of the study. This is what happened to the authors, who share some of these challenges and opportunities in their reflections regarding their role as ethnographers in an ethnonursing study with immigrant Ukrainian nurses in Portugal.

\section{REFERENCES}

1. Leininger M. Culture Care Diversity and Universality Theory and evolution of the ethnonursing method. In: Leininger M, Mcfarland MR. Culture care diversity and universality: a worldwide nursing theory. $2^{\mathrm{a}}$ ed. Boston (US): Jones and Bartlett Publishers, Inc.; 2006. p.1-41.

2. Leininger M. Culture Care Diversity and Universality: a theory of nursing. Boston (US): Jones and Bartlett Publishers, Inc.; 2001.

3. Leininger M. Transcultural nursing: concepts, theories, research \& practices. $2^{\mathrm{a}}$ ed. New York (US): McGraw-Hill; 1995.

4. Leininger M. Qualitative research methods in nursing. Orlando (US): Grune \& Stratton; 1985. 
5. Welch A. Cuidar cultural: teoria da diversidade $\mathrm{e}$ da universalidade. In: Tomey AM, Alligood MR. Teóricas de enfermagem e a sua obra (modelos e teorias de enfermagem). $5^{\text {a }}$ ed. Loures (PT): Lusociência; 2004. p.563-91.

6. Monticelli M, Boehs AE, Guesser JC, Gehrmann T, Martins M, Manfrini GC. Aplicações da teoria transcultural na prática da enfermagem a partir de dissertações de mestrado. Texto Contexto Enferm. 2010 Abr-Jun; 19(2): 220-8.

7. George JB, Belcher JR, Bennett AM, Crane MD, Cross JR, Falco SM. Teorias de enfermagem: dos fundamentos à prática profissional. $4^{\mathrm{a}}$ ed. São Paulo (SP): ARTMED; 2000.

8. Campinha-Bacote J. A model of practice to address cultural competence in rehabilitation nursing. Rehabil Nurs. 2001 Jan-Feb; 26(1): 8-11.

9. Simmons M. Insider ethnography: tinker, tailor, research or spy? Rehabil Nurs. 2007; 14(4):7-17.

10. Vasconcelos TMS. Onde pensas tu que vais? Sentate! - Etnografia como experiência transformadora. ESC. 1996 Dez; 6:23-46.

11. Lapasaran AS. Learning the ethnonursing methodology within the domain of filipino elders residing in a nursing home in Northern Nevada [thesis]. Reno (US): Graduate School of University of Nevada. Masters of Science in Nursing; 2003.
12. Spangler ZSS. Nursing care values and caregiving practices of Anglo-American and Philippine-American nurses conceptualized within Leininger's theory [thesis]. Detroit (US): Graduate School of Wayne State University. Doctorate in Philosophy; 1991.

13. Viégas LS. Reflexões sobre a pesquisa etnográfica em psicologia e educação. Diálogos possíveis [online]. 2007 [acesso 2011 Mar 20]; Jan-Jun. Disponível em: http://www.fsba.edu.br/dialogospossiveis

14. Spradley JP. Participant observation. New York (NY): Holt Rinehart and Winston; 1980.

15. Leininger M. Ethnonursing research method and enablers. In: Leininger M, Mcfarland MR. Culture Care Diversity and Universality: a worldwide nursing theory. $2^{\mathrm{a}}$ ed. Boston (MA): Jones and Bartlett Publishers, Inc.; 2006. p.43-81.

16. Costa AF. A pesquisa de terreno em sociologia. In: Silva AS, Pinto JM, organizadores. Metodologia das ciências sociais. $6^{\text {a }}$ ed. Porto (PT): Edições Afrontamento; 1986. p.129-148.

17. Cardoso MAGM. O cuidar em gerontologia: uma análise etnográfica da prática dos enfermeiros [tese]. Porto (PT): Instituto de Ciências Biomédicas Abel Salazar da Universidade do Porto. Curso de Mestrado em Ciências de Enfermagem; 2000.

18. Barton TD. Understanding practitioner ethnography. Nurse Res. 2008; 15(2):7-18. 